\title{
Investigation the Effect of Colloconstructural Corpus-based Instruction on Pragmalinquistic Knowledge of Request Speech Act: Evidence from Iranian EFL Students
}

Batoul Sabzalipour, Mansour Koosha*, Akbar Afghari

Department of English, Isfahan (Khorasgan) Branch, Islamic Azad University, Isfahan, Iran

Corresponding Author: Mansour Koosha, E-mail: mansour.koosha@yahoo.com

\section{ARTICLE INFO}

Article history

Received: June 02, 2017

Accepted: July 15, 2017

Published: December 01, 2017

Volume: 6 Issue: 7

Special Issue on Language \& Literature Advance access: September 2017

Conflicts of interest: None Funding: None

\begin{abstract}
The current study investigated the effect of using colloconstructional corpus-based instruction on enhancing the pragmalinguistic knowledge of speech acts of request among intermediate EFL learners. The fundamental idea was that whether providing students with on-line corpora through using colloconstruction had any effects on enhancing their pragmalinguistic knowledge of request speech act. In such doing, 60 intermediate-level subjects from several institutions in Mazandaran province, in Iran, participated in the study. Then, the subjects took a standard Oxford Placement Test (OPT) to demonstrate their English proficiency. Based on the obtained scores, they were randomly administered as two equal groups $(\mathrm{N}=30)$. A WDCT pre- test was conducted in each group to examine their ability and knowledge in using speech acts of request. After 15 sessions of treatment, a WDCT posttest was conducted. The experimental group received corpus-based instruction through colloconstructional practices. In contrast, the control group only practiced learning the same speech act through traditional and old methods of learning speech acts like textbooks, audios and videos. The data were analyzed using paired and independent sample t- test. To boost the results validity, the researcher used observation and interview, too. The results revealed that speech act learning was enhanced by corpus-based instruction. Some theoretical and pedagogical implications of the study were then presented.
\end{abstract}

Key words: Colloconstruction, Corpus-based Instruction, Speech Acts, WDCT

\section{INTRODUCTION}

Language is an invention and a process through which human beings engage in communicative interactions with others. Intrinsically, it is in principle close to the social context in which it is set. Pragmatics is fundamentally about interaction between semantic content, contextual information, and general communicative pressures and guides discourse participants in filling in these drafts, how language users signify the context of utterance, and central aspects of the context to communication. Intonation, physical gesture, and social identity are aspects of linguistic performance which can transfer meaning, and many fields can assert to aspects of the above initial questions, including sociolinguistics, philosophy, discourse analysis, dialogue management, cognitive psychology and artificial intelligence.

Over the past four decades, the corpus-based approach to linguistics and language education has increased importance, mainly since the mid-1980s. As corpus analysis can be revealing in virtually all divisions of linguistics or language learning. One of the powers of corpus data lies in its practical nature, which pools together the insights of a great number of speakers and makes linguistic analysis more impartial. Obviously, corpora have been used widely in almost all branches of linguistics, for example, grammatical studies, contrastive and translation studies, lexicographic and lexical studies, language variation studies, diachronic studies, stylistics, discourse analysis, language pedagogy, semantics, pragmatics, sociolinguistics and forensic linguistics. Corpora have passed into general usage in linguistics despite the fact that they still rarely attract aggressive criticism.

Interlanguage Pragmatics (ILP) is about speech act theory (e.g., requests, apologies), conversational implicature theory, politeness theory in general, and deixis and assumption in a more definite way with the pragmalinguistics and sociopragmatics emphasis. Many learners and teachers and stockholders are challenged by interlanguage pragmatic development in EFL settings. Speech acts are the most important issues among different classifications of pragmatics.

Within different types of speech act, "request" is used most. There are different ways to teach to Learners in EFL settings. Ellis (1992) and Sawyer (1992) emphasize the role of context and sociopragmatic knowledge of speech acts. Some studies in interlanguage reveal that sociopragmatic failure may often cause more serious communicative mistakes than grammatical errors and even may be measured aggressive by native speakers rather than simply being viewed as language errors. The speaker may feel silly, helpless or offensive, or from the viewpoint of the listener, feeling con- 
fused, insulted or angry. Moreover, the result shows that grammatical competence does not suggest pragmatic competence, or, in other words, grammatically advanced learners do not essentially have associated pragmatic competence. In conclusion, pragmatic failure may adversely affect learners' learning, stopping them from interacting with native speakers in the most required.

Dippold (2009) argues that a decontextualized manner and a linguistic discourse can be useful in improving pragmatic knowledge. But the way pragmalinguistic is taught is also significant as these lexico-grammatical chunks do not go to any linguistic category on tree diagrams and providing grammatical descriptions is not a prpoer way for teaching them.

Additionally, the traditional methods using a limited number of textbooks including small number of exercises are not responsive to the variety of speech acts. In most classrooms, textbook hardly ever provides enough information for students to gain pragmatic competence. The textbook of most speech acts is pragmatically inadequate.

Corpus pragmatics is a relative newcomer on the pragmatic and the corpus-linguistic scene. For a long time pragmatics and corpus linguistics were regarded "as parallel but often mutually exclusive" (Romero-Trillo, 2008. p. 2). However in recent years corpus linguists and pragmaticists have actively begun exploring their common ground. Because of the methodological problems on one hand and scarcity of the recourses and materials in traditional text-book based methods on the other hand, online corpora using colloconstruction as grammatical models (Stefanowitsch \& Gries, 2008) can also be very influential here. Collections of Internet- based documents created ad hoc as a response to specific context (Zanettin 2002, p. 242) can be used through instruction.

Zhao and Throssell (2011) investigated Speech Act Theory and its priority to language teaching. They used on line corpora and concluded that because of the abundance of different speech acts in culturally various contexts; language students should find out relevant rules of speech acts or be aware of the pragmalinguistic aspect. Richly explained about dialogue corpora (Pieraccini \& Eckert, 2000) and user replication (Schatzmann, Georgila \& Young, 2005; Schatzmann,Georgila, Wolters \& Moore, 2008) are used for new research directions in speech act practices. The results of using corpora were sufficient. The focus of Stefanowitsch and Gries (2008) was on the role of collocation, colligation, and colloconstruction for teaching lexico-grammar through using corpora in EFL situations. Bijari, Mehrdad and Karimi (2014) investigated the apologizing and requesting. The findings revealed the efficiency of using corpora on teaching speech acts. The present study is planned to study whether using on-line corpora and performing pragmalinguistic aspects of speech act of request through colloconstruction, as an alternative to the traditional teaching approaches, can solve the problems regarding learning of speech acts or not.

\section{Research Question}

1. Does colloconstructional online corpus-based instruction have any effect on enhancing Iranian intermediate
EFL learners pragmalinguist knowledge of speech act of request?

\section{Hypothesis}

H0: Colloconstructional online corpus-based instruction has no effect on enhancing enhancing Iranian intermediate EFL learners pragmalinguist knowledge of speech act of request.

\section{REVIEW OF RELATED LITERATURE}

Speech act theory has mainly concerned about Interlanguage Pragmatics theory. Types of speech act include: apology, complaint, and compliment. The theory of speech acts is very important for the understanding of language. First, J. L. Austin (1975) makes a distinction between utterances that are tested, and perceived utterances. The request speech act is one of the most widely observed speech acts. In detail, a request contains an illocutionary. Then, this speech act has is one of the most face-threatening speech acts. Because of its high frequency this speech act has established much attention in ILP research for years. Recently, since the methodological problems on one hand, and insufficiency of the recourses and materials in traditional text-book based methods on the other hand, online corpora using colloconstruction as grammatical model has been satisfying.

Polcz (2012) investigated conventionally indirect speech acts in English-Hungarian film script translation. It was a colloconstructionally concerned with sty because corpora provided frequency for certain acts. Two pragmalinguistic forms were selected for the determinations of the present research, suggestion and request. The focus of pragmalinguistic analysis is on the question whether a given surface form is suited to show the same predictably indirect speech act in the source and the target languages, and what variances can be revealed between first language and second language speech acts in the category of indirectness/directness and linguistic respect. Linguistic data was found from first language and second language corpora. The source language corpus includes the scripts of episodes of American TV series in computer: processable digital format amounting to 497 hours of film material. Many different genres were included in the corpus, such as comedies, crime series, hospital series, family drama, teenage and fantasy series. 200 pieces of data were found from each surface form amounting to 1000 pieces of linguistic data overall. The findings revealed that both direct and indirect transfer occur in the process of translation. Changing the directness category is encouraged by the source language specificity of the pragmalinguistic form, and furthermore by the sociopragmatic variables. The phenomenon of negative and positive transfer has been recognized and defined to account for the translation of speech acts.

Tagushi (2006) examined Japanese learners of English request role plays with regard to suitability and linguistic terms. The findings proposed that the control of linguistic items was better by high-proficient. As for hints, they improved significantly according to the difficulty of the perfor- 
mances in groups. She concluded that it could be called sensitivity to situational elements. He added on that proficiency increased speech act production quality.

Alfattah and Ravindranath (2009) investigated Yemeni EFL learners' politeness strategies in IL requests. The results revealed that Arabic language did not distinguish between the present and past forms of modal verbs pragmatically. In another study, Al-Ali and Alawneh (2010) studied the mitigating devices in English Jordanian learners' mitigating devices. They found out that Jordanian learners expressed definite cultural items in words of obligation etc.

Finally, the use of corpora can be satisfying in the teaching and learning process. In spite of the significant role that textbooks and other instructional materials play in teaching and learning English as a foreign language in Iran, few researches conducted to corpus-based materials and approaches. The present study examines the effect of this type of corpus-based instruction on learning speech act of request.

\section{METHODOLOGY}

\section{Participants}

The subjects of this study were students of English-Language institutes in Mazandaran province. They were selected from the target population of intermediate EFL learners. There was no age and sex limitation. The criterion for selection was an Oxford Placement Test (OPT) in which scores between 120-149, 60 participants, based on Krejcie and Morgan's table for random sample size (1970) with 95\% confidence interval, were randomly selected and randomly divided into experimental and control groups, thirty in each group. The intermediate level was selected because they are cognitively ready to receive metacognitive instruction and process speech act tasks.

\section{Design}

The design of this study was the quasi- experimental design. In this study on-line corpus was the independent variable practiced through colloconstruction, and speech act of request was the dependent variable. Samples were selected from several institutions in Mazandaran, Iran. Administrating OPT, they were assigned into experimental and control groups. A Written Choice Discourse Completion Test (DCT) was administered to groups as the pretest. Then, the experimental group was exposed to corpus-based instruction of speech acts of request. The control groups did not received corpus-based instruction, but they were taught in traditional teaching methods for speech acts. After 15 sessions, a post test was run. The results were analyzed to see whether treatment had any impact or not.

\section{Materials}

The materials used in the current study were those utilized in traditional classes and the ones used in corpus-based classes

\section{In traditional classes}

The students had several sources of authentic materials to observe and analyze speech act samples. They listened to audios, watched filmed scenes and reviewed their transcripts for the request speech act studied during the semester. The class also studied EFL textbooks taught in these institutes about American culture and communication in order to understand the cultural context that shapes how speech acts are done. The approximate level of these textbooks was intermediate to upper-intermediate.

\section{In corpus based classes}

a. Corpus like Communicator that is called dialogue corpora was used. These corpora are speech act- special and contain topics concerning speech act practice. It is a keyword-based parser. So, for colloconstruction analysis, keywords are used for providing information concerning speech acts. The validity and reliability of these corpora had been substantiated through a pilot study done on 4 students to make sure it is suitable for intermediate level students.

b. CARLA site was also be used as a source for exercises and practicing request speech act.

\section{Instruments}

Several instruments were employed in the present study:

As for the proficiency test, OPT test was employed. The test has been developed by the Languages and Linguistic Faculty members and therefore, enjoys the construct validity crucial to any developed test. Krejcie and Morgan's table for random sample size (1970) and two 10 item WDCT (Written choice discourse completion test) for speech act of request as the pretest and the posttest were also used in this study. The reliability and validity of these tests were confirmed beforehand; all of these situations were taken from the previous studies. Attraction and reliance mode model. (Gries, 2008. $\mathrm{p}, 657$ ) was used for scoring request DCT. Here scoring was based on the number of speech acts written and their importance from the most important to the least ones. In addition devices like videos, audio containing situations containing interviews and meetings with celebrities, computers and internets were employed for the instruction.

\section{Procedures}

The subjects were selected from the target population of Iranian intermediate EFL learners. A test to measure homogeneity of subjects called Oxford Placement Test (OPT) was administered with 100 questions, fifty for each skill and 60 subjects with scores between 120 to 149 were selected, and randomly assigned as experimental and control groups. A pre- test of WDTC was administered to determine their primary speech act knowledge. The subjects were required two write more than two variety of a single speech act of request. Then the treatment started and lasted for one semester, 15 sessions twice a week. Each treatment session lasted half 
an hour. Colloconstruction was introduced and practiced in experimental group. The type of material was also different in which corpora were used in these classes. They were exposed to dialogues and different examples containing different forms of speech acts in different real life situations from dialogue corpora. The researcher explained what colloconstruction is and some examples were shown through corpora. The subjects became familiar with their application and use of corpora. Some of the applications were installed by the researcher beforehand. As an alternative, the way online corpora can be downloaded and practiced was also trained. The subjects were requested to find some instances of request speech act. Then, they started searching for other varieties of the same act. Dialogue corpora is key word- based.The key words were given, and the speech act used in different situation appeared on the screen. The subjects observed how, in frequent example, a special speech act can appear in different forms. Dialogue corpora also exist online. The subjects can download and use it in this way. After enough practicing through corpora, the students started working on the speech act of request through role play because it is an integrated skill and all skill is practiced through it. Then, some exercises taken from CARLA website were given to the subjects to see whether they were able to write different varieties of requesting. But the control groups practiced the speech acts through traditional methods of teaching through speech act related materials extracted by researcher from EFL textbooks, audios and videos CDs. All the Subjects were given:

1. Awareness activities.

2. Authentic language samples as examples or models.

3. Production activities.

At the end of each class session the researcher gave some exercises taken from CARLA website. The subjects were required to do the exercises for more practice. By the end of the semester a WDTC posttest was run with questions specified speech act of request to see whether there would be any difference between traditional and corpus group or not. Then, data was analyzed and codified based on attraction and reliance (Gries., 2008. p, 657). They are scored based on the number of forms they write for a single request statement and their importance. In order to increase the validity of result, field notes that were based on Observations and interview was also used.

\section{Data Analysis}

The participants' scores on the pretest and posttest were calculated by SPSS software. Then two types of data analysis statistical procedures are used: descriptive statistics and inferential statistics. As an inferential statistical procedure, paired sample T-test was used to see the subjects' improvement from pre-tests to post tests. Independent sample t-test using subjects' scores in posttest was run to ensure any significant difference between participants' responses to the situations in posttests.

\section{RESULTS}

The present study was aimed to investigate whether there were any significant differences between the control as the non-corpus and experimental group as the corpus group or not. The null hypothesis predicted no relationship and no treatment effect. Students' responses were observed and analyzed concerning the changes and differences displayed in their speech act improvement after they used the on-line dialogue corpora. After analyzing students' scores on the pretests and the post tests, two statistical analyses of the data was carried out, descriptive and inferential. Table 1 displays the descriptive analysis of pre-test and post test scores of the control group of request with the mean of $9.85, \mathrm{SD}$ of 4.12 for the pre-test and mean of 10.16 and SD of 4.05 for the posttest. As the table shows, there is a little improvement from pretest to post-test that is not significant.

Table 2 presents the descriptive analysis of pre-test and post test scores of experimental group. The mean is 9.56 and the SD is 3.91 for the pre-test and 12.53 and 3.97 for the post-test. The difference between pre-test and post-test is evident here. So it shows the treatment was effective.

Table 3 shows the results of Paired sample t-test between pre-test and post test scores of control group. The observed $-t$ is 1.00 with the significance level of 0.00 . It is less than the critical-t (2.00). So the difference between pre-test and post-test is not significant.

Table 4 shows the results of Paired sample t-test between pre-test and post test scores of experimental group received colloconstructional corpus-based instruction. The observed $-t$ is 9.83 exceeding the critical-t with the significance level of 0.00 that is less than.05. It shows the effectiveness of treatment in experimental group.

Table 5 summarizes an independent sample T-test to compare the post-test scores of experimental and control group. The observed-t is 2.20 and greater than the critical- $t$ which is 2.00. The p-value (two- tailed) is.02. Hence. the treatment was influential in experimental group.

\section{DISCUSSION}

In view of the research question, the results of the paired-samples t-test of the participants' pre-test and post-test scores and independent sample t-test between the post test scores

Table 1. Descriptive analysis of the pre-test and post test scores of the control group

\begin{tabular}{ccccc}
\hline & Mean & $\boldsymbol{N}$ & $\begin{array}{c}\text { Standard } \\
\text { desviation }\end{array}$ & $\begin{array}{c}\text { Standard } \\
\text { error mean }\end{array}$ \\
\hline CON & & & & \\
Pre & 9.85 & 31 & 4.1 & 0.74 \\
Post & 10.16 & 31 & 4.05 & 0.72 \\
\hline
\end{tabular}

Table 2. Descriptive analysis of the pre-test and post test scores of the experimental group

\begin{tabular}{ccccc}
\hline & Mean & $\boldsymbol{N}$ & Standard deviation & $\begin{array}{c}\text { Standard } \\
\text { error mean }\end{array}$ \\
\hline EXP & & & & \\
Pre & 9.5 & 30 & 3.91 & 0.71 \\
Post & 12.53 & 30 & 3.97 & 0.72 \\
\hline
\end{tabular}


Table 3. Paired sample t-test between pre-test and post test scores of control group

\begin{tabular}{|c|c|c|c|c|c|c|c|}
\hline & \multicolumn{4}{|c|}{ Paired differences } & \multirow[t]{3}{*}{$t$} & \multirow[t]{3}{*}{ df } & \multirow[t]{3}{*}{ Sig. (2-tailed) } \\
\hline & \multirow[t]{2}{*}{ Mean \pm SD } & \multirow[t]{2}{*}{ Standard error mean } & \multicolumn{2}{|c|}{$\begin{array}{l}95 \% \text { confidence interval of } \\
\text { the difference }\end{array}$} & & & \\
\hline & & & Lower & Upper & & & \\
\hline $\begin{array}{l}\text { Pair } 1 \\
\text { pre-post }\end{array}$ & $0.37 \pm 0.66$ & 0.11 & 0.84 & 0.35 & 1.00 & 30 & 0.000 \\
\hline
\end{tabular}

Table 4. Paired sample t-test between pre-test and post test scores of experimental group

\begin{tabular}{|c|c|c|c|c|c|c|c|}
\hline & \multicolumn{4}{|c|}{ Paired differences } & \multirow[t]{3}{*}{$t$} & \multirow[t]{3}{*}{ df } & \multirow[t]{3}{*}{ Sig.(2-tailed) } \\
\hline & \multirow[t]{2}{*}{$\operatorname{Mean} \pm$ SD } & \multirow[t]{2}{*}{ Standard error mean } & \multicolumn{2}{|c|}{$\begin{array}{l}95 \% \text { confidence interval of } \\
\text { the difference }\end{array}$} & & & \\
\hline & & & Lower & Upper & & & \\
\hline $\begin{array}{l}\text { Pair } 1 \\
\text { pre-post }\end{array}$ & $2.9 \pm 0.81$ & 0.14 & 3.27 & 2.66 & 9.83 & 29 & 0.000 \\
\hline
\end{tabular}

Table 5. Independent samples t-test between post test scores of experimental and control groups

\begin{tabular}{|c|c|c|c|c|c|c|c|c|c|}
\hline & \multicolumn{2}{|c|}{$\begin{array}{l}\text { Levene's test } \\
\text { for equality of } \\
\text { variances }\end{array}$} & \multicolumn{7}{|c|}{$t$-test for equality of means } \\
\hline & \multirow[t]{2}{*}{$\mathbf{F}$} & \multirow[t]{2}{*}{ Significant } & \multirow[t]{2}{*}{$t$} & \multirow[t]{2}{*}{ df } & \multirow[t]{2}{*}{ Sig. (2-tailed) } & \multirow[t]{2}{*}{$\begin{array}{l}\text { Mean } \\
\text { difference }\end{array}$} & \multirow[t]{2}{*}{$\begin{array}{l}\text { Standard error } \\
\text { difference }\end{array}$} & \multicolumn{2}{|c|}{$\begin{array}{l}95 \% \text { confidence } \\
\text { interval of the } \\
\text { difference }\end{array}$} \\
\hline & & & & & & & & Lower & Upper \\
\hline \multicolumn{10}{|l|}{ Post 2} \\
\hline $\begin{array}{l}\text { Equal variances } \\
\text { assumed }\end{array}$ & 0.030 & 0.86 & 2.20 & 58 & 0.021 & 2.25 & 1.01 & 4.28 & 0.21 \\
\hline
\end{tabular}

of experimental and control group showed that the participants' could increase their speech act ability through using corpora. Thus the null hypothesis that colloconstructional corpus-based instruction has no impact on improving the speech act knowledge of subjects of this study is rejected.

The results of this study is according to studies done by Polcz (2012) who do a corpus- based study on conventionally indirect speech acts in English-Hungarian film script translation that was colloconstructionally concerned with because corpora provided frequency for identified acts. Two pragmalinguistic forms were chosen for the determinations of the present research, suggestion and request. As findings revealed, both direct and indirect transfer occur in the process of translation. Corpora and colloconstructional analysis helped to influence this result.

The findings of the current present study are in line with the findings of previous studies that have been done in the context of using corpus-based activities (e.g. Chao, 2010; Chujo, Utiyama \& Miura, 2006; Gaskell \& Cobb, 2004; Gilmore, 2009). All of these studies have attempted to explore the effectiveness of the corpus-based instruction on EFL/ESL learners' performance on English language. For instance, Chujo, Utiyama and Miura (2006) did a study to find out the effectiveness of Japanese-English bilingual corpus-based instruction on beginner level EFL learners' learning. The findings revealed that the beginning level EFL learners were able to utilize the bilingual corpus-based instruction effectively to learn English.

The results of the study also are consistent with the study done by Alfattah and Ravindranath (2009) who focused on the politeness strategies in IL requirements accomplished by Yemeni EFL learners for the modals can and could. In addition, Ghanmi (2014) Birjandi and Karimi (2014) believe in the role of other factors, but the present study confirms the efficiency of using colloconstructional corpus-based instruction on improving the pragmalinguistic knowledge speech act of request. The results of observation and interview were also satisfying for the use of corpora and the experimental group was fulfilled with this teaching method.

\section{CONCLUSION}

This paper presented the effective results of applying on-line corpus-based instruction on improving pragmalinguistics knowledge of speech acts of request among Iranian Intermediate EFL learners. The results revealed a distinction between the corpus-based instruction and traditional teaching methods of speech acts based on the teaching methodology and instructional material as evaluated by post-tests. The findings revealed that colloconstruction as a corpus-based teaching approach, can develop the pragmalinguistic knowledge of speech act of request. The corpus provides inference and 
pedagogical value via authentic examples. A corpus-based approach provides opportunities to students by giving authentic examples with which they would see the correct language use. According to Flowerdew (1993), by using fabricated examples, students may understand a "distorted picture of actual use" (p. 23). Colloconstruction provide frequency for a certain act in the whole corpus, and also present different varieties of single acts and their applications in different situations through frequent authentic examples. With different forms, Learners can learn more than a single act and can adopt them better through real-life examples. While the current study' results showed employing corpus-based language learning in an EFL setting, the limitations of the research include small sample size, controlling of the subjects and confusing variables like age, sex, intelligence, and psychological factors can change the results of the study. The future study should consider the application and use of computer technology resources, computer-assisted language learning method in the classes in which only traditional ways are worked on. As results and the limitations of the current research show suggestions for future research to better understand the using of a corpus-based research in speech act learning. First, the study focused on speech act of request, the question, then, might be whether the use of corpora in other speech acts can also be useful. The second point is the importance of this study on the pragma linguistic knowledge of speech acts. Consequently, corpus-based instruction and using colloconstruction as a corpus-based and grammatical approach can develop the quality of learning by presenting example from authentic contexts and causes having a more significant and comprehensible product. By sociopragmatic concentration study, intermediate levels of the subjects were chosen for the purpose of this study. A research can be done on advanced levels can study the effectiveness of this approach in this level. However, the same study can be simulated by other subjects of different ages, levels and sexes. The future researchers can study in the field of psychology or other fields of studies. The final point is pragmatics itself in which is not limited to speech acts. Researchers can use corpus-based instructions in other fields of pragmatics like conversational implicature, deixes and conversational structural studies with the same or different approach to study its effectiveness or ineffectiveness.

\section{REFERENCES}

Al-Ali, M. N., \& Alawneh, R. (2010). Linguistic mitigating devices in American and Jordanian students' requests. Intercultural Pragmatics, 7(2), 311-339.

Alfattah, G. \& Ravindranath, H. (2009) Probabilistic methods in spoken dialogue systems. Philosophical Transactionsapologies (pp. 197-220). Norwood, New Jersey: Ablex.

Austin N, J. (1975). How to do things with words: The Wiliam James lectures delivered at Harvard University in 1955. Oxford: Clarendon Press.

Bijari, M., Mehrdad, F. \& Karimi, T. (2014) Data-driven learning and teaching collocation of prepositions: The case of Iranian EFL adult learners. Asian EFL Journal
Quarterly, 8(4), 192-209.

Birjandi, P., \& Rezaei, S. (2010). Developing a multiple-choice discourse completion test of interlanguage pragmatics for Iranian EFL learners. ILI Language Teaching Journal, 6(2), 43-58.

Chao, P. (2010). A study of collocation learning of junior high students in Taiwan via concordance. Paper presented at the 2010 international conference on English teaching, Kaohsiung, Taiwan. Retrieved 14.02.2011, from. http://www2.kuas.edu.tw/edu/afl/20100430Final/ Word/2010comp_EPCA.pdf.

Chui, K., Utiyama, M., \& Miura, S. (2006). Using a Japanese-English parallel corpus for teaching English vocabulary to beginning-level students. English Corpus Studies, 13, 153-172.

Dippold, D. (2009). Face and self-presentation in spoken L2 discourse: Renewing the research agenda in interlanguage pragmatics. Intercultural Pragmatics, 6(1), 1-28.

Ellis, R. (1992). "Learning to communicate in the classroom. "Studies in Second Language Acquisition, 14, 1-23.

Flowerdew, K. (1993). Exploring the pragmatics of interlanguage pragmatics: Definition by design in Anna Trosborg(Ed.) In Pragmatics across Languages and Cultures, Handbooks of Pragmatics, vol. 7, (pp. 219-259). Berlin: DeGruyter Mouton

Ghanmi, F. (2014). Gender Differences in the Use of Apology Speech Act in Persian, International Journal of Linguistics, 6(6).

Gries, S. (2008). Problems in the comparison of speech acts across cultures. In S. Blum-Kulka, J. House \& G. Kasper (Eds.), Cross-cultural pragmatics: Requests and apologies (pp. 174-196). Norwood, New Jersey: Ablex

Pieraccini, G. \& Eckert, P. (2000). 'Variation and the indexical field'. Journal of Sociolinguistic, 12(4), 453-476.

Polcz, K. (2012). Az angol diskurzusaktusok direktségi szintjének változása a magyarra fordított filmszövegekben. In: Zimányi, Á. (szerk.) A tudomány nyelve - A nyelv tudománya. A XIX. Magyar Alkalmazott Nyelvészeti Kongresszus előadásai. Eger, April 16-18 2009. Eger: B.V.B Nyomda és Kiadó Kft. 190-198

Romero-Trillo, J. (ed.) (2008). Pragmatics and corpus linguistics. A mutualistic entente. Berlin and New York: Mouton de Gruyter.

Sawyer, M. (1992). The development of pragmatics in Japanese as a second language: Thesentence-final particle ne. In G. Kasper (Ed.), Pragmatics ofJapanese as a Nativeand Foreign Language. Technical Report, 3 (83125), Second Language Teaching \&Curriculum Center, University of Hawaii at Manoa.

Schatzmann, J., Georgila, S. \& Young, B. (2005). Statistical user simulation with a hiddenagenda. In Proceedings of the 8th SIGdial Workshop on Discourse and Dialogue, Antwerp, Belgium(pp. 273-82).

Schatzmann,J, Georgila, S, Wolters, B. \& Moore, W. (2008). A survey of statisticaluser simulation techniques for reinforcement-learning of dialogue management strategies. Engineering Review 21(2): 97-126.

Stefanowitsch, A. Gries, S. (2008), Collostructions: Investigating the Interaction between Words and Construc- 
tions. International Journal of Corpus Linguistics, $8(2)$, 209243.

Tagushi, N. (2006). Analysis of appropriateness in a speech act of request in L2 English. Journal of Pragmatics, 16(4), 513-533.

Zanettin, F. (2002). Parallel words: Designing a bilingual database for translation activities. In A. Wilson \& T. McEnery (Eds.), Corpora I: language education and research:
A selection of papers from talc9, Concept 'Concept'", New Trends in Conceptual Representation Challenges to Piaget's Theory?, Hillsdale(N.J.), Lawrence Erlbaum Assoc.

Zhao, D. \& Throssell, F. (2011) New Outline of pragmatics. Shanghai: Shanghai Foreign Language. Education Press. Computer Science, Trinity College, Dublin, TCDCS-93-11. 